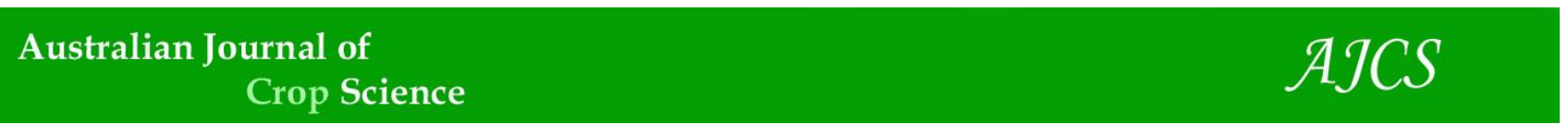

AJCS 14(09):1394-1398 (2020)

ISSN:1835-2707

doi: 10.21475/ajcs.20.14.09.p2373

\title{
Addition of preservatives to minimally processed 'BRS Kampai' peaches (Prunus persica L.)
}

\section{Caroline Farias Barreto* ${ }^{1}$, Renan Navroski ${ }^{1}$, Roseli de Mello Farias ${ }^{2}$, Marines Batalha Moreno Kirinus ${ }^{3}$, Carlos Roberto Martins ${ }^{4}$, Marcelo Barbosa Malgarim ${ }^{1}$}

\author{
${ }^{1}$ Universidade Federal de Pelotas, Capão do Leão, RS, Brazil \\ ${ }^{2}$ Universidade Estadual do Rio Grande do Sul, São Borja, RS, Brazil \\ ${ }^{3}$ Instituto Federal de Educação, Ciência e Tecnologia Sul-Rio-Grandense, Campus Pelotas Visconde da Graça, \\ Pelotas, RS, Brazil \\ ${ }^{4}$ Empresa Brasileira de Pesquisa Agropecuária, Clima Temperado, Pelotas, RS, Brazil
}

\author{
*Corresponding author: carol_fariasb@hotmail.com
}

\begin{abstract}
Fruits that go through processes of sanitation, peeling, cutting and packaging, to be consumed soon afterwards, are called minimally processed fruits. Since fruit consumption is important in the human diet, consumers have looked for practicality in both preparation and consumption, a situation that includes minimally processed food. However, minimal processing can damage plant tissues, mainly by pulp browning and by accelerating changes in natural characteristics of the product. This study aimed at minimizing changes in minimally processed sliced peaches by immersing them in solutions which contained preservatives. The experiment was a completely randomized design in a $5 \times 3$ factorial scheme ( 5 anti-browning agents $\times 3$ storage periods), with 4 trays per replicate and six slices of peaches in every replicate. Sliced fruits were treated with $\mathrm{T} 1=$ control (distilled water); $\mathrm{T} 2=$ ascorbic acid at $1 \%(\mathrm{~m} / \mathrm{v}) ; \mathrm{T} 3=$ sodium isoascorbate at $1 \%(\mathrm{~m} / \mathrm{v}) ; \mathrm{T} 4=$ ascorbic acid at $0.5 \%(\mathrm{~m} / \mathrm{v})+$ sodium isoascorbate at $0.5 \%$ $(\mathrm{m} / \mathrm{v})$; and $\mathrm{T} 5$ = citric acid at $0.5 \%(\mathrm{~m} / \mathrm{v})+$ sodium isoascorbate at $0.5 \%(\mathrm{~m} / \mathrm{v})$. Afterwards, they were placed on trays, covered with $9 \mu$ PVC film and stored at $4 \pm 1$ 으 for 0 (S1), 6 (S2) and 12 (S3) days. The following variables were evaluated: mass loss, pulp color, pulp firmness, soluble solids, titratable acidity, $\mathrm{pH}$, rot spots, total phenols and antioxidant activity. The treatment that consisted of citric acid at $0.5 \%(\mathrm{~m} / \mathrm{v})+$ sodium isoascorbate at $0.5 \%(\mathrm{~m} / \mathrm{v})$ was the most efficient one to control oxidation; its values of browning indexes were the lowest ones, i. e., 15.62 (S1), 17.74 (S2) and 17.58 (S3). Besides, it kept the creamy-white color of the pulp throughout storage time.
\end{abstract}

Keywords: bioactive compounds; physicochemicals; Prunus persica; quality; storage duration.

Introduction

Minimally processed fruits are products that are submitted to processes of cleaning, washing, peeling, cutting and packaging, even though their quality is similar to the one of fresh products since they keep their nutritional and sensory characteristics (Mendoza-Goméz et al., 2017). The minimally processed fruit segment has developed due to changes in fruit consumption patterns. The market has required quality fruits that are easy to prepare (Oms-Oliu et al., 2010). Search for easy preparation and quality products have valued minimally processed products (Simões et al., 2019). Minimal processing, which is a way of using production surplus and adding value to products, is inserted in this context (Marques et al., 2011).

Processing of minimally processed fruits constitutes a large segment of the food processing industry worldwide. It generates opportunities for innovation in food processing, development of new products and projects of packaging, besides increase in their sales at commercial scales (Yousuf et al., 2018).

The cultivar 'BRS Kampai', which originated from the crossing between cultivars 'Chimarrita' and 'Flordaprince', was developed by the Embrapa Clima Temperado, located in
Pelotas, RS, Brazil, and launched in 2010. It stands out not only due to its content of total soluble solids of its fruits but also because of their white pulp, semi-free stone, sweet flavor, slight acidity and suitability for fresh consumption (Raseira et al., 2014). Peaches borne by the cultivar 'BRS Kampai' have been well accepted by consumers as fresh products. However, due to the short harvest period and high perishability, peaches need either immediate commercialization or consumption after harvest or some storage method to extend their preservation period (Pegoraro et al., 2015). An alternative is the commercialization of minimally processed peaches, but it has been limited by immediate physiological responses of tissues to wounds (Martins et al., 2013).

Peaches are naturally perishable fruits; when they are minimally processed, degradation intensifies due to the respiratory rate and ripening metabolism (Costa et al., 2011). Besides, most peach cultivars are highly sensitive to enzymatic browning (Girner et al., 2002; Costa et al., 2011), one of the most important limitations of minimally processed products. The main enzymatic browning route starts with the oxidation of endogenous phenols by 
polyphenoloxidase (PPO) in the presence of oxygen. Thus, quinone is formed and its subsequent polymerization leads to the formation of dark pigments called either melanin or melanoidin, besides loss of aroma, nutritional properties and useful life of fruits (Vasconcelos and Filho, 2010).

Some studies of minimally processed peaches have been carried out to extend their useful life, decrease pulp browning and keep fruit firmness (Chagas et al., 2008; Costa et al., 2011; Allegra et al., 2015). However, tissue cutting of minimally processed fruits exposes cells and favors the activity of enzymes that cause tissue browning and softening (Mendoza-Goméz et al., 2017).

Several preservation methods, such as the use of some products - citric and ascorbic acids - which are antioxidant compounds that may avoid enzymatic browning, tissue ripening and loss of nutritional quality, have been used for trying to decrease adverse effects throughout the preparation of minimally processed products (Kluge et al., 2014; Ambuko et al., 2017; Mendoza-Goméz et al., 2017). Studies of the use of sodium isoascorbate in minimally processed apples and avocados have also been carried out, since this compound is capable of decreasing the activity of enzymes that are responsible for fruit deterioration, such as PPO, which causes browning (Martins et al., 2011; Barreto et al., 2016; Mendoza-Goméz et al., 2017).

Based on the fact that both citric and ascorbic acids and sodium isoascorbate may extend shelf life of fruits, the use of these products, in combination or separately, is believed to prevent enzymatic browning and preserve the texture of 'BRS Kampai' peaches, thus, extending preservation of minimally processed fruits. Therefore, this study aimed at evaluating the efficiency of using isolated and combined preservatives to keep the quality of minimally processed peaches for up to 12 days.

\section{Results and discussion}

\section{Pulp browning and pulp color}

Pulp browning was mitigated by using preservatives in minimally processed peach preservation. Browning indexes of minimally processed peaches were lower after 0,6 and 12 storage days in the $C A+S I$ treatment (Table 1). The evaluation carried out throughout the development of the treatments showed gradual increase in pulp browning in both $A A$ and $A A+S I$ treatments. Browning was more accentuated on the 12th storage day, i. e., peach pulp got reddish-cream.

Evaluation of pulp color showed that all anti-browning agents under investigation had similar behavior regarding pulp browning. On the 6th storage day, no difference was found among anti-browning agents concerning pulp color of minimally processed peaches (Table 1 ). However, on the 12th day, pulp color was stronger in peaches that underwent the $\mathrm{CA}+\mathrm{SI}$ treatment, i. e., it kept creamy-white, by comparison with the $A A+S I$ treatment. Pulp browning is one of the main problems of minimally processed products because when fruits are cut, enzyme activity is favored and tissue browning occurs (Mendoza-Goméz et al., 2017). As a result, pulp browning affects the color of fruit surfaces directly, a fact that corresponds to an important quality attribute of commercialization (Jang and Moon, 2011).

Most peach cultivars are highly sensitive to enzymatic browning (Girner et al., 2002). Oxidative stress is a problem that limits shelf life, mainly the one of peaches that have white pulp, such as 'BRS Kampai' ones. Therefore, this experiment showed the positive effect, mainly of the combination $\mathrm{CA}+\mathrm{SI}$, on the maintenance of the natural color of minimally processed 'BRS Kampai' peaches after a 12-day storage period.

Values of ${ }^{\circ}$ Hue decreased after the 12-day $\mathrm{AA}, \mathrm{AA}+\mathrm{SI}$ and $\mathrm{CA}+\mathrm{SI}$ treatments applied to minimally processed 'BRS Kampai' peaches. Similar result was reported by GonzálezBuesa et al. (2011), who found that values of ${ }^{\circ}$ Hue decreased after a 9-day treatment applied to minimally processed 'Andross' peaches.

\section{Pulp firmness and soluble solids}

Pulp firmness of minimally processed peaches after a 12-day storage period kept the highest means in the $C A+S I$ treatment, while the lowest values were found in the control (Table 2). Pulp firmness loss throughout storage was found mainly in the control treatment, a fact that may result from the loss of cell turgor, changes in the characteristics of middle lamella polysaccharides on the cell wall and activity of hydrolytic enzymes or non-enzymatic mechanisms, due to the activity of ethylene (Chitarra and Chitarra, 2005).

Soluble solids of minimally processed peaches exhibited the highest values when AA was applied on the 6th storage day (Table 2). However, their contents did not show any significant difference on the 12th storage day. In general, throughout all storage periods, there was increase in soluble solid concentrations. According to Chitarra and Chitarra (2005), several chemical and biochemical reactions, such as decrease in acidity and increase in soluble solid contents, occur in the ripening process of fruits. Such phenomena were observed by this study; it implies that, at the end of the storage period, fruits were starting their senescence stage.

\section{Titratable acidity and $\mathrm{pH}$}

The highest titratable acidity was found in minimally processed peaches that were treated with $\mathrm{CA}+\mathrm{SI}$, on the 6th day (Table 3), while it was higher in the ones that were treated with $\mathrm{CA}+\mathrm{SI}$ and $\mathrm{AA}+\mathrm{SI}$, on the 12th day, by comparison with the SI treatment. Decrease in titratable acidity in minimally processed peaches was found throughout all storage, except in the AA+SI treatment, when values differed very little in the storage process. According to Chagas et al. (2008), contents of titratable acidity and pH of minimally processed 'Regis' peaches varied among storage days. Decrease in values of titratable acidity may have occurred because fruit metabolism is intensified when fruits are handled and, consequently, organic acids are consumed (Brackmann et al., 2009).

On day 0,6 hours after the preparation of minimally processed peaches, their $\mathrm{pH}$ was higher in the control (Table 3) than in the other treatments. On the 6th storage day, there were no differences among treatments. On the 12th day, the use of $A A+S I$ and $C A+S I$ kept $p H$ values higher than the control treatment. Regarding $\mathrm{pH}$, in general, values decreased throughout storage, except in the case of AA+SI, which kept the same values on the days under evaluation.

\section{Total phenol and antioxidant activity}

Total phenol concentrations were higher in peaches treated with $A A$ and $A A+S I$ on the 6th day, while, on the 12th, the highest concentrations were found in $\mathrm{AA}, \mathrm{SI}$ and $\mathrm{CA}+\mathrm{SI}$ (Table 4). No straight connection could be established 
Table 1. Mean values of browning indexes and pulp color ('Hue) of minimally processed 'BRS Kampai' peaches treated with antibrowning agents, Pelotas 2019.

\begin{tabular}{|c|c|c|c|c|c|c|}
\hline \multirow[t]{2}{*}{ Preservatives } & \multicolumn{2}{|l|}{ Day 0} & \multicolumn{2}{|l|}{ Day 6} & \multicolumn{2}{|l|}{ Day 12} \\
\hline & \multicolumn{6}{|c|}{ Browning indexes } \\
\hline Control & 18.59 & $a b c A$ & 20.50 & $a b A$ & 19.21 & $\mathrm{bcA}$ \\
\hline $\mathrm{AA}$ & 19.07 & $a b B$ & 21.53 & $\mathrm{aAB}$ & 22.84 & $\mathrm{aA}$ \\
\hline SI & 20.67 & $\mathrm{aA}$ & 19.25 & $a b A$ & 19.88 & $a b A$ \\
\hline$A A+S I$ & 16.52 & $b c B$ & 18.05 & $b B$ & 20.87 & $a b A$ \\
\hline $\mathrm{CA}+\mathrm{SI}$ & 15.62 & $\mathrm{cA}$ & 17.74 & $\mathrm{bA}$ & 17.58 & $\mathrm{cA}$ \\
\hline \multirow[t]{2}{*}{ CV (\%) } & \multicolumn{6}{|l|}{8.31} \\
\hline & \multicolumn{6}{|c|}{ Pulp color } \\
\hline Control & 101.08 & $\mathrm{bA}$ & 102.15 & $\mathrm{aA}$ & 100.05 & $a b A$ \\
\hline AA & 103.76 & $a b A$ & 100.37 & $\mathrm{aAB}$ & 98.12 & $a b B$ \\
\hline SI & 101.69 & $\mathrm{bA}$ & 102.85 & $\mathrm{aA}$ & 101.59 & $a b A$ \\
\hline$A A+S I$ & 103.52 & $a b A$ & 102.42 & $\mathrm{aA}$ & 95.47 & $\mathrm{bB}$ \\
\hline $\mathrm{CA}+\mathrm{SI}$ & 108.53 & $\mathrm{aA}$ & 105.44 & $\mathrm{aAB}$ & 102.50 & $\mathrm{aB}$ \\
\hline
\end{tabular}

Ascorbic acid (AA), sodium isoascorbate (SI), ascorbic acid + sodium isoascorbate (AA+SI), citric acid + sodium isoascorbate (CA+SI). Means followed by equal letters, lowercase in columns and uppercase in lines, do not differ by the Tukey's test, at $5 \%$ probability $(p \leq 0.05)$.

Table 2. Pulp firmness and soluble solids of minimally processed 'BRS Kampai' peaches treated with anti-browning agents, Pelotas 2019.

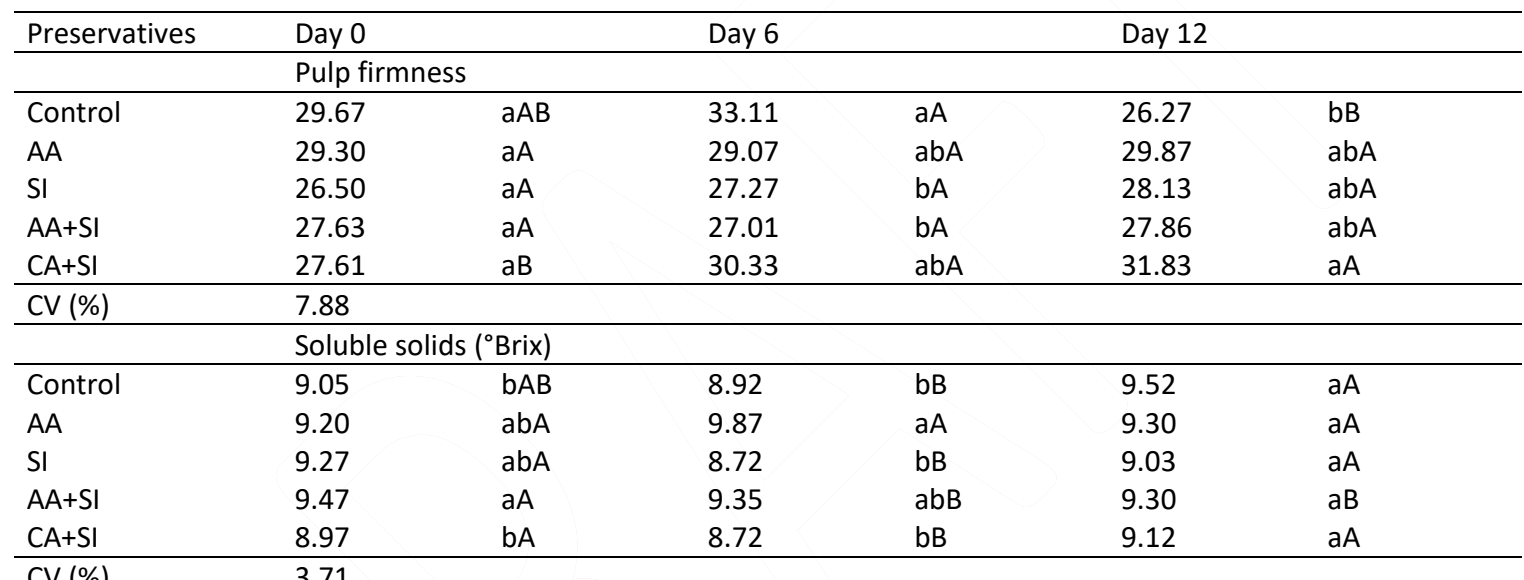

Ascorbic acid (AA), sodium isoascorbate (SI), ascorbic acid + sodium isoascorbate (AA+SI), citric acid + sodium isoascorbate (CA+SI). Means followed by equal letters, lowercase in the columns and uppercase in the lines, do not differ by Tukey's test, at $5 \%$ probability $(\mathrm{p} \leq 0.05)$.

Table 3. Titratable acidity and pH of minimally processed 'BRS Kampai' peaches treated with anti-browning agents, Pelotas 2019.

\begin{tabular}{lllllll}
\hline Preservatives & Day 0 & \multicolumn{3}{l}{ Day 12} \\
\hline & \multicolumn{2}{l}{ Titratable acidity } & & & & \\
\hline Control & 0.61 & aA & 0.44 & abB & 0.40 & abC \\
AA & 0.53 & bA & 0.40 & bB & 0.41 & abB \\
SI & 0.47 & cA & 0.42 & abB & 0.38 & bC \\
AA+SI & 0.47 & cA & 0.44 & abA & 0.43 & aA \\
CA+SI & 0.48 & bcA & 0.45 & aAB & 0.43 & aB \\
\hline CV (\%) & 5.43 & & & & & \\
\hline & pH & & & & & \\
\hline Control & 3.33 & aC & 3.79 & aB & 4.09 & aA \\
AA & 3.12 & bC & 3.80 & aB & 3.97 & abA \\
SI & 3.22 & abC & 3.87 & aB & 4.00 & abA \\
AA+SI & 3.24 & abB & 3.79 & aA & 3.91 & bA \\
CA+SI & 3.19 & abC & 3.74 & aB & 3.93 & bA \\
\hline CV (\%) & 1.95 & & & & & \\
\hline
\end{tabular}

Ascorbic acid (AA), sodium isoascorbate (SI), ascorbic acid + sodium isoascorbate (AA+SI), citric acid + sodium isoascorbate (CA+SI). Means followed by equal letters, lowercase in the columns and uppercase in the lines, do not differ by Tukey's test, at $5 \%$ probability $(p \leq 0.05)$. 
Table 4. Total phenols and antioxidant activity of minimally processed 'BRS Kampai' peaches treated with anti-browning agents, Pelotas 2019.

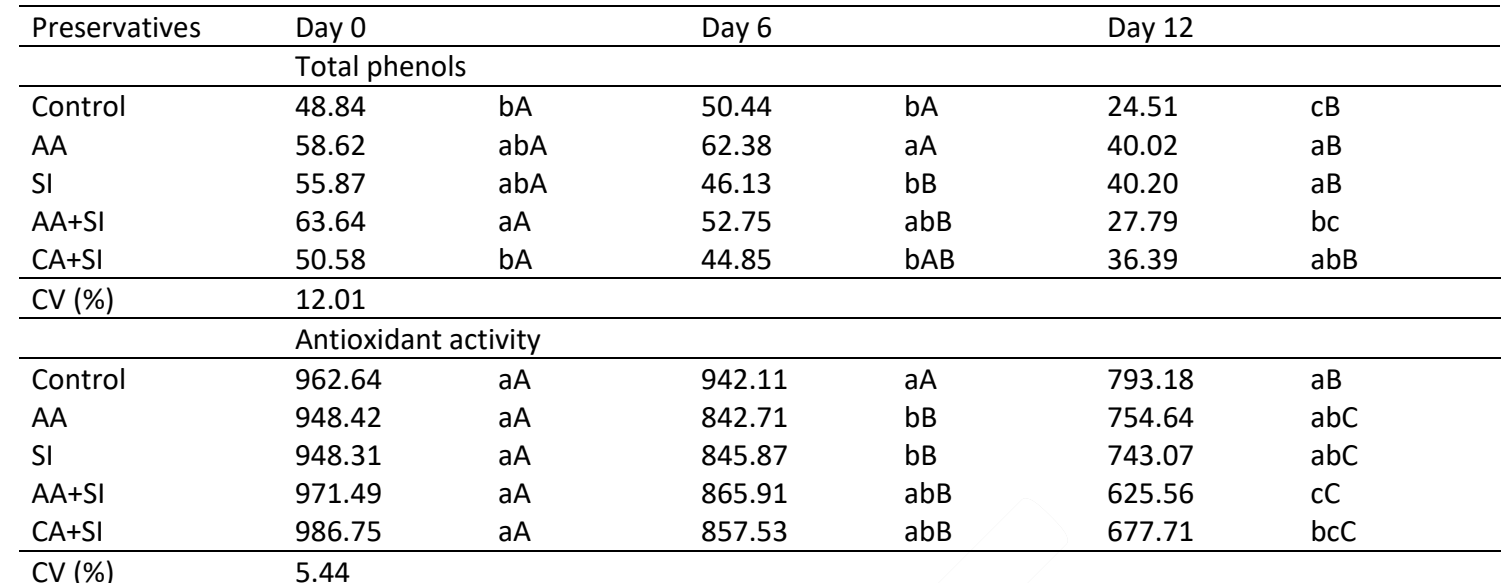

Ascorbic acid (AA), sodium isoascorbate (SI), ascorbic acid + sodium isoascorbate (AA+SI), citric acid + sodium isoascorbate (CA+SI). Means followed by equal letters, lowercase in the columns and uppercase in the lines, do not differ by Tukey's test, at $5 \%$ probability $(p \leq 0.05)$.

between anti-browning agents and storage periods, since changes in responses depended on the day. According to Santos et al. (2013), phenolic compounds in peaches differ among cultivars and among storage periods.

Anti-browning agents used by this study affected antioxidant activity of peaches after 6 and 12 storage days. Control, $\mathrm{AA}+\mathrm{SI}$ and $\mathrm{CA}+\mathrm{SI}$ treatments led to the highest concentrations on the 6th storage day, while, on the 12th day, control, AA and SI treatments exhibited the highest ones (Table 4). Antioxidant properties are very much related to the cultivar and cultivation conditions, such as the environment and management techniques (Scalzo et al., 2005; Santos et al., 2013).

In general, there was decrease in concentrations of total phenols and antioxidant activity throughout storage (Table 4). It may be related to the ripening stage, since the riper the fruit, the lower the contents of total phenolic compounds and antioxidant activity (Siriwoharn et al., 2004; Castrejon et al., 2008). Decrease in contents of phenolic compounds after storage may result from their high oxidation at cold temperatures (Severo et al., 2010) and during the accelerated process of fruit ripening (Vieites et al., 2012).

\section{Materials and methods}

\section{Plant material}

Peaches were harvested in an orchard in Eldorado do Sul, Rio Grande do Sul (RS), Brazil. They were borne by the cultivar 'BRS Kampai' grafted on the rootstock 'Capdeboscq'. In the 6-year-old orchard, plants are conducted in a vase system, whose spacing among rows and plants is $5.5 \mathrm{~m}$ and $2.5 \mathrm{~m}$, respectively. Peaches were harvested when their back color was greenish cream. After harvest, peaches were taken to the Laboratório LabAgro at the Universidade Federal de Pelotas, located in Pelotas, RS, Brazil, where minimal processing was carried out.

\section{Treatments and experimental design}

The experiment was a completely randomized design in a $5 \times 3$ factorial scheme (5 anti-browning agents $\times 3$ storage periods), with 4 trays per replicate, and six slices of peaches in every replicate.

Fruits were sanitized with sodium hypochlorite at 200ppm at room temperature for 10 minutes. Every peach was sliced into 6 segments and the core with the stone was removed with the use of a sterilized stainless steel knife. Peach slices were immersed in solutions with the following treatments for 2 minutes $\mathrm{T} 1=$ control (distilled water); $\mathrm{T} 2=$ ascorbic acid $(\mathrm{AA})$ at $1 \%(\mathrm{~m} / \mathrm{v}) ; \mathrm{T} 3=$ sodium isoascorbate $(\mathrm{SI})$ at $1 \%$ $(\mathrm{m} / \mathrm{v}) ; \mathrm{T} 4=$ ascorbic acid $(\mathrm{AA})$ at $0.5 \%(\mathrm{~m} / \mathrm{v})+$ sodium isoascorbate $(\mathrm{SI})$ at $0.5 \%(\mathrm{~m} / \mathrm{v}) ; \mathrm{T} 5=$ citric acid $(\mathrm{CA})$ at $0.5 \%$ $(\mathrm{m} / \mathrm{v})+$ sodium isoascorbate $(\mathrm{SI})$ at $0.5 \%(\mathrm{~m} / \mathrm{v})$. Afterwards, 8 peach slices were placed on expanded polystyrene trays $(300 \times 230 \times 33 \mathrm{~mm})$, which were covered with stretchable $9 \mu$ PVC film. Mean weight of every tray was $200 \mathrm{~g}$. Trays were stored in cold chambers at $4 \pm 1$ OC $\mathrm{C}$ at $85-90 \%$ relative humidity $(\mathrm{RH})$. Minimally processed peaches treated with antioxidants underwent cold storage and were analyzed after 0 ( 6 hours after preparation) (S1), 6 (S2) and 12 days (S3).

\section{Traits under evaluation}

In order to monitor peach preservation throughout storage, the following variables were evaluated. Fresh mass loss considered the difference between the initial mass of minimally processed peaches and the one found at the end of every storage period, in the formula: pulp color measured by a Minolta $\mathrm{CR}-300^{\circledR}$ colorimeter with a D65 light source, expressed as the system of rectangular coordinates $L^{*}, a^{*}$, $\mathrm{b}^{*}$, in agreement with the Commission Internationale de I'Eclairage $(\mathrm{CIE})$, where $\mathrm{L}^{*}$ is expressed as luminosity values, $a^{*}$ represents red $(+)$ or green $(-)$ and $b^{*}$ is yellow $(+)$ or blue $(-)$. These parameters led to the evaluation of the Hue angle coordinates and the browning index (BI), whose calculation was carried out in agreement with Fontes et al. (2008). Pulp firmness was measured by a manual MCCornick FT 327 penetrometer, with a 6-mm diameter tip, and readings were expressed as Newton (N). Soluble solids were determined by a digital Atago ${ }^{\circledR}$ refractometer and expressed as ${ }^{\circ}$ Brix of the juice. Titratable acidity was determined by diluting $10 \mathrm{~mL}$ juice in $90 \mathrm{~mL}$ distilled water; it was then titrated with $\mathrm{NaOH}$ 0.1 to $\mathrm{pH} 8.1$ and results were expressed as percentage of citric acid (\% citric acid). Hydrogenionic potential $(\mathrm{pH})$ was measured by a Quimus $\mathrm{pH}$ meter. Total phenolic compounds were determined by the method based on the reaction with the Folin-Ciocalteau reagent, in agreement with the method adapted from Singleton and Rossi (1965); results were expressed as $\mathrm{mg}$ gallic acid equivalent/100g sample (GAE $\left.100 \mathrm{~g}^{-1}\right)$. Antioxidant activity was determined by the DPPH 
radical method adapted from Brand-Williams et al. (1995) and results were expressed as $\mathrm{mg}$ Trolox equivalent/100 $\mathrm{g}^{-1}$ fruit. Data were submitted to the analysis of variance $(p \leq 0.05)$.

\section{Statistical analysis}

When statistical significance was found, the analysis of means was carried out by the Tukey's Test $(p<0.05)$.

\section{Conclusion}

The combination of anti-browning agents citric acid + sodium isoascorbate preserves the quality of minimally processed peaches which are stored at 4 으 \pm 1 으 for 12 days. The use of citric acid + sodium isoascorbate helps to maintain pulp color, firmness and browning indexes of minimally processed peaches after a 12-day preservation period. Minimally processed peaches with no addition of anti-browning agents have their pulp firmness and content of phenolic compounds decreased after a 12-day preservation period. Regardless of the use of anti-browning agents, there was decrease in concentrations of total phenols and antioxidant activity during storage days.

\section{References}

Allegra A, Barone E, Inglese P, Todaro A, Sortino G (2015) Variability of sensory profile and quality characteristics for "Pesca di Bivona" and "Pesca di Leonforte" peach (Prunus persica Batsch) fresh-cut slices during storage. Postharvest Biol Tec. 110:61-69.

Ambuko J, Kemunto N, Hutchinson M, Owino W (2017) Comparison of the Postharvest Characteristics of Mango Fruits Produced under Contrasting Agro-Ecological Conditions and Harvested at Different Maturity Stages. J Agr Sci. 9:181-192.

Barreto CF, Kirinus MBM, Silva PS, Farias R de $M$, Malgarim MB, Martins CR (2016) Use of additives in combination with UV-C for the conservation of minimally processed 'Fuji Suprema' apples. Afr J Agr Res. 11:4917-4923.

Brackmanni A, Weberi A, Giehl RFW, Eisermann AC (2009) Préresfriamento sobre a qualidade de pêssegos 'Chiripá'. Cienc Rural. 39:2354-2360.

Brand-Willians W, Cuvelier ME, Berset C (1995) Use of a free radical method to evaluate antioxidant activity. Food Sci Technol-Leb. 28:25-30.

Castrejon ADR, Eichholz I, Rohn S, Kroh LW, Huyskens-Keil S (2008) Phenolic profile and antioxidant activity of highbush blueberry (Vaccinium corymbosum L.) during fruit maturation and ripening. Food Chem. 109:564-572.

Costa AC, Antunes PL, Rombaldi CV, Gularte MA. (2011) Controle do escurecimento enzimático e da firmeza de polpa em pêssegos minimamente processados. Cienc Rural. 41:1094-1101.

Chagas PC, Shirahige FH, Silva PPM, Spoto MHF, Chagas EA (2008) Avaliação da qualidade de pêssegos 'Regis' minimamente processados. B.CEPPA. 26:179-186.

Chitarra MIF, Chitarra AB (2005) Pós-colheita de frutas e hortaliças: fisiologia e manuseio. 2.ed. Lavras, FAEPE, 783p.

Fontes LCB, Sarmento SBS, Spoto MHF, Dias CTS (2008) Preservation of minimally processed apple using edible coatings. Food Sci TechBrazil. 29:872-880.

Girner J, Ortega M, Mesegue M, Gimeno V, Barbosa-Canovas GV, Martin O (2002) Inativation of peach polyphenoloxidase by exposure to pulsed electric fields. J Food Sci. 67:264-267.
González-Buesa E, Arias E, Salvador ML, Oria R, Ferrermairal A (2011) Suitability for minimal processing of non-melting clingstone peaches. Int J Food Sci Tech. 46:819-826.

Jang JH, Moon KD (2011) Inhibition of polyphenol oxidase and peroxidase activities on fresh-cut

apple by simultaneous treatment of ultrasound and ascorbic acid. Food Chem. 124:444 - 449.

Kluge RA, Geerdink GM, Tezotto-Uliana JV, Guassi SAD, Zorzeto TQ, Sasaki FFC, Mello S da C (2014) Quality of minimally processed yellow bell pepper treated with antioxidants. Semina. 35:801-812.

Martins RN, Mattiuz B, Santos LO, Morgado CMA, Mattiuz CFM (2011) Preservation of minimally processed 'Aurora-1' peaches using additives. Rev Bras Frutic. 33(4):1229-1239.

Martins RN, Mattiuz B, Santos LO, Hojo ETD, Mattiuz CFM (2013) Estádios de maturação de pêssegos 'aurora-1' para o processamento mínimo. Rev Bras Frutic. 35:391-397.

Marques KM, Mattiuz BH, Morgado CMA, Galati VC, Miguel ACA (2011) Formas de preparo de figo-da-índia minimamente processado. Rev Bras Frutic. 3:606-611.

Mendoza-Gómez V, Calderón-Santoyo M, Bautista-Rosales PU Ortiz-Basurto RI, Jimenez-Sánchez DE, Ragazzo-Sánchez JA (2017) Antibrowning agents added in polymeric coating applied to avocado fruit slices. Interciencia. 42:812-817

Oms-Oliu G, Soliva-Fortuny R, Martín-Belloso O (2008) Edible coatings with antibrowning agents to maintin sensory quality and antioxidant properties of fresh-cut pears. Postharvest Biol. Technol, 50:87-94

Pegoraro C, Tadiello A, Girardi CL, Chaves FC, Quecini V, Oliveira AC de, Trainotti L, Rombaldi CV (2015) Transcriptional regulatory networks controlling woolliness in peach in response to preharvest gibberellin application and cold storage. BMC Plant Biol, 15:1-14.

Raseira M do CB, Pereira JFM, Carvalh FLC (2014) Pessegueiro: Embrapa Clima Temperado, Brasília, p.73-142.

Santos CM dos, Abreu CMP de, Freire JM, Correa AD (2013) Antioxidant activity of fruits of four peach cultivars. Rev Bras Frutic. 35:339-344

Severo J, Lima CSM, Coelho MT, Rufatto AR, Rombaldi CV, Silva JA (2010) Antioxidant capacity and phytochemical composition of physalis fruit (Physalis peruviana, L.) during ripening and storage. Rev Bras Agroc. 16:77-82.

Scalzo J, Politi A, Pellegrini N, Mezzetti B, Battino M (2005) Plant genotype affects total antioxidant capacity and phenolic contents in fruit. Nutrition. 21:207-213.

Simões AN, Coelho DG, Fonseca KS, Júnior APB, Ferreira-Silva SL, Freire CS, da Silva EF (2019) Effect of multilayer nylon packages on the oxidative damage of minimally processed yam. Braz. J. Food Technol. 22:e2017090.

Singleton VL, Rossi JAJR (1965) colorimetry of total phenolic with phosphomolybdic-phosphotungstic acid reagents. Am J Eno Viticult. 16:144-158.

Siriwoharn T, Wrolstad RE, Finn CE, Pereira CB (2004) Influence of cultivar, maturity, and sampling on blackberry (Rubus L. Hybrids) anthocyanins, polyphenolics, and antioxidant properties. Jour Agric and Food Chem. 52:8.021-8.030.

Vasconcelos MAS, Melo Filho AB (2010) Conservação de Alimentos Recife: EDUFRPE. p.130.

Vieites RL, Daiuto ER, Fumes JGF (2012) Antioxidant capacity and postharvest quality of 'Fuerte' avocado. Rev Bras Frutic. 34:336348

Yousuf B, Qadri OS, Srivastava AK (2018) Recent developments in shelf-life extension of fresh-cut fruits and vegetables by application of different edible coatings: A review. LWT - Food Sci and Technol. 89:198-209. 